\title{
VAPOUR GENERATION CHEMILUMINESCENCE DETECTION SYSTEM FOR DETERMINATION OF DIMETHYLSULPHONIOPROPIONATE AND DIMETHYLSULPHIDE IN TROPICAL SEAWATER
}

\author{
A. E. Adedapo ${ }^{1, *}$, N. U. Benson ${ }^{1, *}$, A. B. Williams ${ }^{1}$ and K. Toda ${ }^{2}$ \\ ${ }^{1}$ Department of Chemistry, Covenant University, P.M.B. 1023, Ota, Ogun State, Nigeria \\ ${ }^{2}$ Department of Chemistry, Kumamoto University, 860-8555, Kumamoto, Japan \\ *E-mail: nsikak.benson@ covenantuniversity.edu.ng \\ adebusayo.adedapo@covenantuniversity.edu.ng
}

\begin{abstract}
The vapour generation - chemiluminescence (VG-CL) detection system that was designed for this research was used for the measurement of dimethylsulphide (DMS) and its precursor dimethylsulphoniopropionate (DMSP). The present study attempted the development of a highly sensitive, portable and cost-effective detection system based on vapour generation and chemiluminescence for a pilot assessment and determination of DMSP and DMS concentrations in the Gulf of Guinea. The Elegushi Beach and Nigerian Institute of Oceanography and Marine Research (NIOMR) which are parts of the Atlantic Ocean were chosen as designated locations for this study. The average concentrations of DMSP and DMS in the surface seawater at the two locations ranged from $12.4 \pm 0.2$ to $26.5 \pm 0.5 \mathrm{nM}, 2.1 \pm 0.0$ to $40.9 \pm 1.6 \mathrm{nM}$ and $9.7 \pm 0.4$ to $44.9 \pm 0.2 \mathrm{nM}, 0$ to $35.6 \pm 2.3 \mathrm{nM}$, respectively. This study serves as a baseline measurement of the concentrations of DMS and DMSP in the tropical Atlantic Ocean (Lagos).
\end{abstract}

Keywords: Dimethylsulphide, Dimethylsulphoniopropionate, Seawater, Vapour Generation Chemiluminescence Detection

○ RASĀYAN. All rights reserved

\section{INTRODUCTION}

The production of Dimethylsulphoniopropionate (DMSP) by certain species of the marine algae and plant halophytes such as coccolithophores in high concentrations helps to regulate their internal osmotic surroundings. ${ }^{1,2,3,4}$ The synthesis of DMSP originate from methionine in both plant and algae but have a different pathway. The viral lysis, grazing and stress on phytoplankton produced DMSP by zooplankton and microbial attack. ${ }^{5,6}$ Its concentration ranges from 5-50 nM, and sometimes greater than $100 \mathrm{nM}$ during blooms of DMSP produced from algae. ${ }^{7,8}$ Since DMSP comprises of $1-10 \%$ of the carbonate in dissolved carbon $\left(\mathrm{pCO}_{2}\right)$, making DMSP an important part of the dissolved organic carbon, no other compound has been known to contribute to the linking of phytoplankton DMSP to the microbial food web. ${ }^{9-11}$ Being the blooms of gigantic coccolithophore which was found in the North Sea, DMSP can reach up to $10 \%$ of the total carbon fixed. ${ }^{12,13}$ DMSP is also known to contribute to all the sulphur requirement in the microbes and dislocation. ${ }^{14}$ Most importantly, DMSP is a readily metabolisable monomer with no previous hydrolytic enzyme activity to release it. ${ }^{15}$ Thus, DMSP is a link between the primary production and the microbial population. ${ }^{15}$ The increase in the bacterial biomass in the numerous studies frequently show several delays for many days after the phytoplankton room formation. DMSP is produced through the cleavages of DMSP mainly by marine bacterial DMSP lyases. ${ }^{16,17}$ Dimethylsulphide (DMS) production is the key step in the global sulphur cycle and is the sulphur compound gas needed to enable the study between the marine and the terrestrial environment. ${ }^{18,19}$

Rasayan J. Chem., 13(1), 44-50(2020)

http://dx.doi.org/10.31788/RJC.2020.1315432 
It was proposed that the DMS produced from the biological environment undergoes many DMS oxidative products to form cloud condensation nuclei, thereby reducing the amount of sunlight reaching the earth, and decreasing the global mean temperature. ${ }^{20-22}$ Such a phenomenon will have negative feedback on the marine community that generated the DMS. ${ }^{23,24}$

In fact, DMS and DMSP play a key role in the marine microbial food web, global sulphur cycle and even in the global climate which explained the intense studies on the biochemical pathway in the last three decades. ${ }^{25}$ Nevertheless, in comparison to other regions, the Gulf of Guinea has received little or no attention as regarding the measurements, distribution and emission of biogenic sulphur in the seawater. ${ }^{26,27,28}$

In view of this, the vapour generation - chemiluminescence (VG-CL) detection system was fabricated to be used for the determination of DMS and DMSP in the seawater. ${ }^{28}$ The focus of this study was, therefore, to use the fabricated and re-modified VG-CL to determine the concentration of DMS and DMSP in the samples of the seawater collected from the tropical Atlantic Ocean around Lagos State (Elegushi and NIOMR). ${ }^{29,30}$

\section{Materials and Method}

\section{Sample Location}

Lagos Lagoon $\left(6^{\circ} 27^{\prime} \mathrm{N} 3^{\circ} 23^{\prime} \mathrm{E}\right)$ is one of Africa's largest estuaries. It is about $6354 \mathrm{~km}^{2}$ in surface area, about $50 \mathrm{~km}$ long and $3-13 \mathrm{~km}$ wide and is located within the Lagos region, cutting across the southern part of the metropolis. It also links the Lekki Lagoon (in the eastern part) and Atlantic Ocean (in the western and southern part) and Fig.-1 shows the locations where the samples were collected.

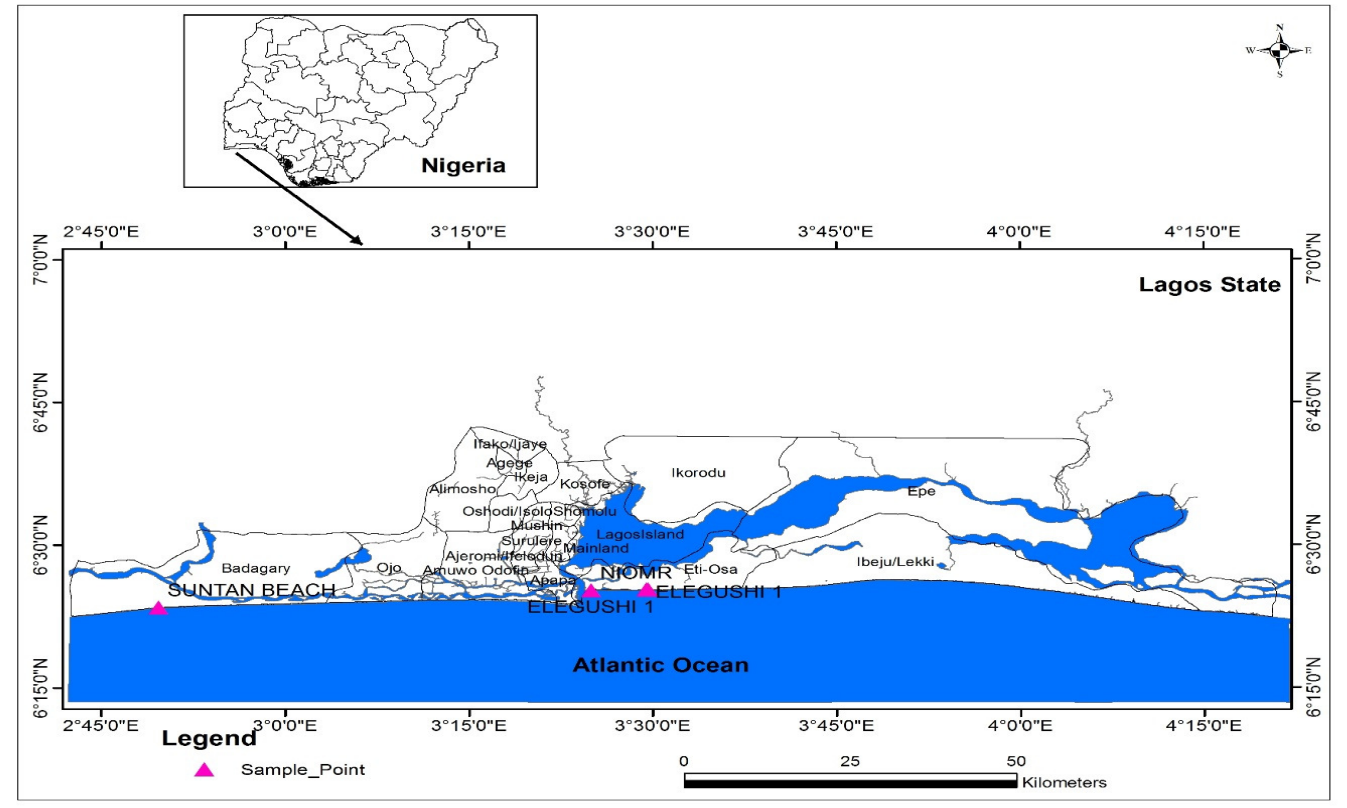

Fig.-1: Map of Gulf of Guinea Showing the Sampling Locations (Insert: Map of Nigeria)

\section{Standards Preparation}

The preparation of the stock solutions of DMS at different concentrations was done using DMS standard (Analytical grade) purchased from Alfa Aesar, Thermo Fisher (Kandel) Germany. $10 \mathrm{mM}$ of DMS and DMSP standards were prepared by dissolving $37 \mu \mathrm{L}$ in $50 \mathrm{~mL}$ in a capped syringe and $0.134 \mathrm{~g}$ in $100 \mathrm{~mL}$ volumetric flask with distilled water, respectively. The preparation of working solutions of DMSP and DMS with their calibrations were carried out according to Nagahata. ${ }^{29,30}$

\section{Sample Preparation}

For DMSP analysis, Seawater samples were collected using the $250 \mathrm{~mL}$ amber bottle. The collection of the seawater samples was done in duplicate at each sampling point. The water samples were subjected to 
aeration using the air pump for the total removal of DMS in the water samples. $200 \mu \mathrm{L}$ of prepared 50 $\mathrm{mM}$ of $\mathrm{Cd}^{2+}$ solution was added to the $10 \mathrm{~mL}$ of the sample prior to analysis to remove any form of interferences and to ensure that only DMSP was analyzed. Syringes with caps were used for the collection of the seawater samples which has been rinsed with the same seawater. The syringes used to prevent the headspace formation that will ease the escape of dissolved DMS. Once the samples were collected, the aluminum foil was being used to wrap it and prevent the light from entering the samples. The collection and the labelling of the seawater samples were done in duplicate at each sampling point. The seawater samples were preserved in the dark and refrigerated at $4{ }^{\mathrm{O}} \mathrm{C}$ before the analysis. ${ }^{29,30}$

\section{VG-CL Analytical Procedure}

The VG-CL detection system is a device that can measure dissolved dimethylsulphide and dimethylsulphoniopropionate in the seawater. Also, dimethylsulphoniopropionate was determined after hydrolysis to dimethylsulphide. The dissolved DMS is extracted to the headspace of the sample tube, and the headspace air is introduced pneumatically to the glass cell together with ozone. The introduced DMS reacts with ozone to produce weak chemiluminescence, which is detected by a photomultiplier tube. The photocurrent is multiplied by a preamplifier and then an amplifier. The signal data is acquired and monitored by the data logger (USB1408FS) for data acquisition with the InstaCard and TracerDAQ (version 2). Figure-2 shows the peak of the DMS standard at various concentrations.

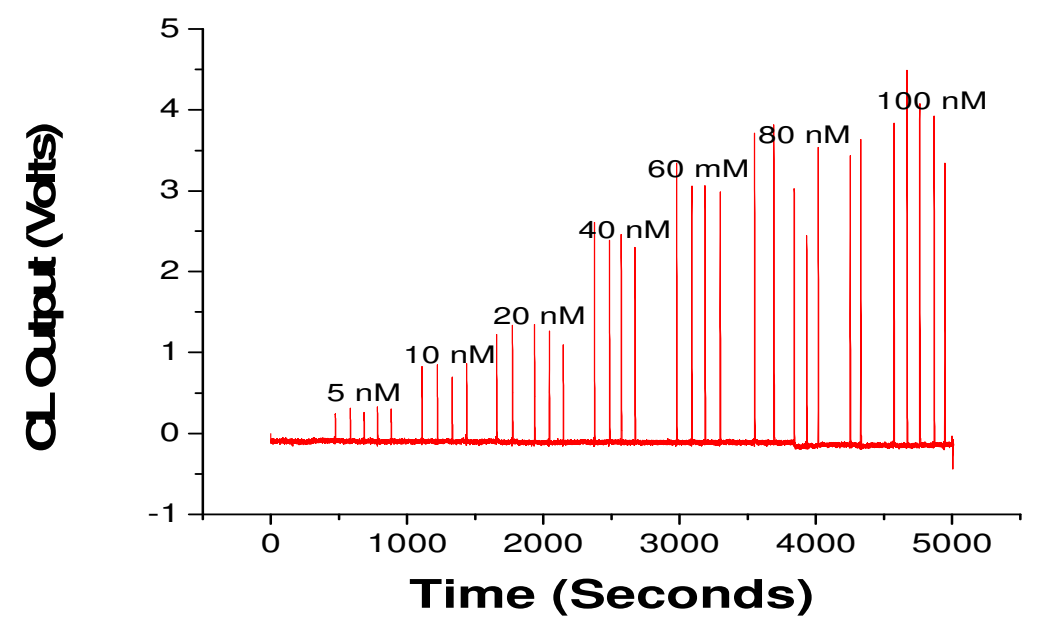

Fig.-2: The VG-CL Signals of the Various Analysed Concentrations of DMS Standards

\section{Descriptive Statistics}

The details are compared in Tables [3-6], which gives a statistical description of all the samples analysed. This shows that there are no significant differences in the samples collected.

\section{RESULTS AND DISCUSSION}

Table-1 shows the concentrations of DMSP of the seawater samples collected at different times at Elegushi Beach. Both samples A and B gave the DMSP concentrations with the lowest and highest average value of $12.4 \mathrm{nM}$ and $26.5 \mathrm{nM}$, respectively. The highest value of DMSP was observed and attained at $11.30 \mathrm{am}$. Table-1 also shows the concentrations of DMSP at different times for the samples collected at NIOMR. The concentration of DMSP was detected in all the samples analysed. Samples A and $\mathrm{B}$ had an average concentration and total concentration of $11.5 \mathrm{nM}$ and $12.5 \mathrm{nM}, 172.7 \mathrm{nM}$ and 188.0 $\mathrm{nM}$, respectively. A striking increase in the concentration of DMSP (24.1 and $26.1 \mathrm{nM}, 39.8$ and 42.0 $\mathrm{nM}$ ) was noticed at 2:30 pm and 2:45 pm for samples A and B, respectively. This high concentration of DMSP might have contributed to the high DMS concentration that was observed in Table-2 as DMSP is a precursor of DMS. This was further corroborated by the very high values of DMS and DMSP obtained within the same time variation of 2:30 to $2: 45 \mathrm{pm}$. It has been reported that intracellular or extracellular 
RASĀYAN J. Chem.

Vol. 13 | No. 1 |44 - 50| January - March | 2020

cleavage of DMSP assisted in the production of DMS which is caused by DMSP-lyase that is synthesized by either algae or bacteria as a result of the secretion of DMSP. ${ }^{31}$

Table-1: Time Concentrations (nM) of DMSP from Elegushi Beach and NIOMR ( $\mathrm{n}=15)$

\begin{tabular}{c|c|c|c|c|c|c}
\hline $\begin{array}{c}\text { Time } \\
(\mathrm{am} / \mathrm{pm})\end{array}$ & Sample A & Sample B & Mean (nM) & Sample A & Sample B & Mean (nM) \\
\hline $10: 00$ & 15.3 & 16.3 & $15.8 \pm 0.7$ & 12.1 & 13.5 & $12.8 \pm 1.0$ \\
\hline $10: 30$ & 18.5 & 19.0 & $18.8 \pm 0.4$ & 10.9 & 9.9 & $10.4 \pm 0.7$ \\
\hline $11: 00$ & 20.2 & 20.5 & $20.4 \pm 0.2$ & 10.6 & 10.9 & $10.8 \pm 0.2$ \\
\hline $11: 30$ & 26.2 & 26.9 & $26.5 \pm 0.5$ & 7.0 & 7.7 & $7.4 \pm 0.5$ \\
\hline $12: 00$ & 16.5 & 17.2 & $16.9 \pm 0.5$ & 8.5 & 8.5 & $8.5 \pm 0.0$ \\
\hline $12: 30$ & 15.4 & 14.9 & $15.2 \pm 0.4$ & 8.2 & 10.5 & $9.4 \pm 1.6$ \\
\hline $1: 00$ & 15.2 & 15.9 & $15.6 \pm 0.5$ & 5.0 & 6.2 & $5.6 \pm 0.8$ \\
\hline $1: 15$ & 16.1 & 16.5 & $16.3 \pm 0.3$ & 4.6 & 6.6 & $5.6 \pm 1.4$ \\
\hline $1: 30$ & 16.1 & 15.5 & $15.8 \pm 0.4$ & 7.5 & 6.8 & $7.2 \pm 0.5$ \\
\hline $1: 45$ & 24.1 & 25.2 & $24.6 \pm 0.8$ & 2.1 & 2.3 & $2.2 \pm 0.1$ \\
\hline $2: 00$ & 15.2 & 16.3 & $15.7 \pm 0.8$ & 2.1 & 8.4 & $5.3 \pm 4.5$ \\
\hline $2: 15$ & 16.6 & 15.5 & $16.0 \pm 0.8$ & 2.1 & 2.1 & $2.1 \pm 0.0$ \\
\hline $2: 30$ & 18.0 & 17.6 & $17.8 \pm 0.3$ & 24.1 & 26.1 & $25.1 \pm 1.4$ \\
\hline $2: 45$ & 15.2 & 15.9 & $15.6 \pm 0.5$ & 39.8 & 42.0 & $40.9 \pm 1.6$ \\
\hline $3: 00$ & 12.2 & 12.5 & $12.4 \pm 0.2$ & 28.1 & 26.5 & $27.3 \pm 1.1$ \\
\hline
\end{tabular}

The concentrations of DMS of the collected samples at Elegushi Beach measured in nanomolar at various times are shown in Table-2. The measured DMS concentration reached $12.1 \mathrm{nM}$ at 1:15 pm. Also, there was a striking increase in the DMS concentration at about 2:00 pm reaching $45.1 \mathrm{nM}$ and at a much higher time of about 2:45 pm, the concentration of DMS in the collected samples dropped to $9.4 \mathrm{nM}$. The observed variations within this timeframe may be due to the intensity of the sunlight at that time as DMS is known to be highly volatile. Also, the rapid increase in DMS concentration for the collected samples A was noticed at 2:00 pm. The highest value recorded was noted in sample A with a value of $45.1 \mathrm{nM}$. A sharp reduction in the concentration of DMS was noted in the samples collected at 2:45 pm. DMS concentrations in sample A ranged between $9.4 \mathrm{nM}$ and $45.1 \mathrm{nM}$. The highest and lowest values in nanomolar of DMS concentration were noticed at 2:00 pm and 2:45 pm respectively. Furthermore, DMS concentration values measured are shown in Table 2. The values ranged from 9.9 to $44.8 \mathrm{nM}$. The lowest value measured in the sample was at 2:45 pm, while the highest was observed at 2:00 pm. Other higher values observed were at time 11:30, 10:30, 1:00 pm and 11:00 pm with values 21.0 nM, 17.0 nM, 14.1 $\mathrm{nM}$ and $14.0 \mathrm{nM}$ respectively. In addition, sharp increment and reduction values in the concentration of DMS in collected sample B were observed at time 2:00 pm and 2:45 pm respectively. In comparing the measured values of concentration of DMS in samples A and B for Elegushi Beach, it was observed that there was minimal difference in the concentration values at the measured time used for this study.

The concentration of DMS was obtained in both samples A and B for NIOMR location with the lowest and highest values of $2.4 \mathrm{nM}$ and $33.3 \mathrm{nM}, 2.5 \mathrm{nM}$ and $37.2 \mathrm{nM}$, respectively with corresponding mean values of $2.4 \pm 0.1 \mathrm{nM}$ and $35.6 \pm 2.3 \mathrm{nM}$. It was noticed that the maximum value of DMS was gotten at 2:45 pm for both samples collected. Table-2 presents the relationship between samples A and B collected at NIOMR. Thus, it can be clarified that both samples analysed has no significant difference. However, it was observed that for both samples collected at NIOMR, there was no detection of DMS concentration at 1:45 and 2:15 pm respectively while at 2:00 pm DMS concentration was not detected for sample A at 2:00 pm. The results obtained indicate that the sea surface temperature had an effect on enhanced biogenic productivity. ${ }^{32}$ According to Sciare $e t a l^{33}$ the rate of DMS efflux from Amsterdam Island in the southern Indian Ocean was an increase of over 50\% following the increase in sea surface temperature (SST) by $1^{\circ} \mathrm{C}$. The findings by Sciare $e t a l^{33}$ are in accordance with the results obtained for this present study. Indicatively, there was a relative increase in the concentration of DMS at 2:00 pm and 2:45 pm for Elegushi Beach and NIOMR locations where samples were collected respectively, with an increase in SST by 2 to $3^{\circ} \mathrm{C}$. Kouvarakis and Mihalopoulos ${ }^{33}$ reported the seasonal variations of gaseous, diurnal 


\section{RASĀYAN J. Chem.}

Vol. 13 | No. 1 |44 - 50| January - March | 2020

variation of DMS and its oxidation products in the Eastern part of the Mediterranean Sea. It was reported that the concentrations of DMS observed at SST ranged from 0.87 to $3.74 \mathrm{nmol} \mathrm{m}^{-3}$ in the winter and summer, respectively. Likewise, it was observed that in the diurnal studies, the DMS concentrations of DMS was very low and rose rapidly at coldest and warmest temperature, respectively. ${ }^{33}$

Table-2: Time concentrations (nM) of DMS from Elegushi Beach and NIOMR location

\begin{tabular}{c|c|c|c|c|c|c}
\hline $\begin{array}{c}\text { Time } \\
(\mathrm{am} / \mathrm{pm})\end{array}$ & Sample A & Sample B & Mean $(\mathrm{nM})$ & Sample A & Sample B & Mean $(\mathrm{nM})$ \\
\hline $10: 00$ & 10.5 & 10.8 & $10.7 \pm 0.2$ & 8.5 & 8.5 & $8.5 \pm 0.0$ \\
\hline $10: 30$ & 16.6 & 17.0 & $16.8 \pm 0.3$ & 6.7 & 5.5 & $6.1 \pm 0.8$ \\
\hline $11: 00$ & 14.0 & 14.1 & $14.0 \pm 0.1$ & 6.5 & 5.4 & $6.0 \pm 0.7$ \\
\hline $11: 30$ & 21.0 & 21.0 & $21.0 \pm 0.0$ & 3.8 & 4.1 & $3.9 \pm 0.2$ \\
\hline $12: 00$ & 13.7 & 13.9 & $13.8 \pm 0.1$ & 4.8 & 4.5 & $4.7 \pm 0.2$ \\
\hline $12: 30$ & 12.6 & 13.3 & $12.9 \pm 0.5$ & 5.0 & 4.1 & $4.6 \pm 0.6$ \\
\hline $1: 00$ & 13.8 & 14.1 & $14.0 \pm 0.2$ & 3.6 & 3.5 & $3.5 \pm 0.1$ \\
\hline $1: 15$ & 12.1 & 11.5 & $11.8 \pm 0.4$ & 2.4 & 2.5 & $2.4 \pm 0.1$ \\
\hline $1: 30$ & 12.8 & 13.1 & $12.9 \pm 0.2$ & 3.3 & 3.3 & $3.3 \pm 0.0$ \\
\hline $1: 45$ & 12.5 & 13.1 & $12.8 \pm 0.4$ & ND & ND & ND \\
\hline $2: 00$ & 45.1 & 44.8 & $44.9 \pm 0.2$ & ND & 8.4 & $4.2 \pm 5.9$ \\
\hline $2: 15$ & 12.9 & 12.9 & $12.9 \pm 0.0$ & ND & ND & ND \\
\hline $2: 30$ & 11.2 & 11.9 & $11.6 \pm 0.5$ & 17.8 & 15.7 & $16.8 \pm 1.4$ \\
\hline $2: 45$ & 9.4 & 9.9 & $9.7 \pm 0.4$ & 33.3 & 37.2 & $35.6 \pm 2.3$ \\
\hline $3: 00$ & 11.5 & 11.3 & $11.4 \pm 0.1$ & 17.3 & 16.1 & $16.7 \pm 0.9$ \\
\hline
\end{tabular}

ND - Not detected

Table-3: Paired Sample Test ( $\mathrm{n}=15$ ) for DMS Concentrations (NIOMR)

\begin{tabular}{|c|c|c|c|c|c|c|c|c|}
\hline & \multicolumn{5}{|c|}{ Paired Differences } & \multirow{3}{*}{$\mathrm{t}$} & \multirow{3}{*}{$\mathrm{df}$} & \multirow{3}{*}{ Sig (2-tailed) } \\
\hline & \multirow[t]{2}{*}{ Mean } & \multirow[t]{2}{*}{ SD } & \multirow[t]{2}{*}{ SEM } & \multicolumn{2}{|c|}{$95 \%$ CI } & & & \\
\hline & & & & Lower & Upper & & & \\
\hline SPL A-SPL B & 1.01 & 1.90 & 0.49 & 2.07 & 0.39 & -2.07 & 14 & 0.058 \\
\hline
\end{tabular}

SPL-sample, SD-standard deviation, SEM-standard error mean, CI- confidence interval

Table-4: Paired Sample Test ( $\mathrm{n}=15)$ for DMS Concentrations (ELEGUSHI)

\begin{tabular}{|c|c|c|c|c|c|c|c|c|}
\hline & \multicolumn{5}{|c|}{ Paired Differences } & \multirow{3}{*}{$\mathrm{t}$} & \multirow{3}{*}{$\mathrm{df}$} & \multirow{3}{*}{ Sig (2-tailed) } \\
\hline & \multirow[t]{2}{*}{ Mean } & \multirow[t]{2}{*}{ SD } & \multirow[t]{2}{*}{ SEM } & \multicolumn{2}{|c|}{$95 \% \mathrm{CI}$} & & & \\
\hline & & & & Lower & Upper & & & \\
\hline SPL A-SPL B & -0.33 & 2.52 & 0.65 & -1.73 & 1.07 & -0.51 & 14 & 0.618 \\
\hline
\end{tabular}

SPL-sample, SD-standard deviation, SEM-standard error mean, CI- confidence interval

Table-5: Paired Sample Test (n=15) for DMSP Concentrations (NIOMR)

\begin{tabular}{|c|c|c|c|c|c|c|c|c|}
\hline & \multicolumn{5}{|c|}{ Paired Differences } & \multirow{3}{*}{$\mathrm{t}$} & \multirow{3}{*}{$\mathrm{df}$} & \multirow{3}{*}{ Sig (2-tailed) } \\
\hline & \multirow[t]{2}{*}{ Mean } & \multirow[t]{2}{*}{ SD } & \multirow[t]{2}{*}{ SEM } & \multicolumn{2}{|c|}{$95 \% \mathrm{CI}$} & & & \\
\hline & & & & Lower & Upper & & & \\
\hline SPL A-SPL B & 1.01 & 1.90 & 0.49 & 2.07 & 0.39 & -2.07 & 14 & 0.058 \\
\hline
\end{tabular}

SPL-sample, SD-standard deviation, SEM-standard error mean, CI- confidence interval

Table-6: Paired Sample Test ( $\mathrm{n}=15)$ for DMSP Concentrations (ELEGUSHI)

\begin{tabular}{c|c|c|c|c|c|c|c|c}
\hline & \multicolumn{5}{|c|}{ Paired Differences } & & & \\
\cline { 5 - 6 } & Mean & SD & SEM & \multicolumn{2}{|c|}{ 95\% CI } & df & Sig (2-tailed) \\
\cline { 5 - 6 } & & & & Lower & Upper & & & \\
\hline SPL A-SPL B & 1.01 & 1.90 & 0.49 & 2.07 & 0.038 & -2.07 & 14.00 & 0.058 \\
\hline
\end{tabular}

SPL-sample, SD-standard deviation, SEM-standard error mean, CI- confidence interval

The massive production of DMS was noticed in this study which has a higher value of DMS concentration compared to the value of DMS reported by Kouvarakis and Mihalopoulos. ${ }^{34}$ This maybe as 


\section{RASĀYAN J. Chem.}

Vol. 13 | No. 1 |44 - 50| January - March | 2020

a result of some environmental factors that assisted in the rapid break down of DMSP. It should be noted that in marine environments, there are many established dominant factors that affect the production of DMS and DMSP. ${ }^{35}$ The factors include the biological and physical processes such as organism interactions at different levels, temperature, light intensity, salinity. ${ }^{35}$ The removal of DMS might be due to the consumption by the bacteria ${ }^{36}$, as a result of this, about $1 \%$ of DMSP produced in the ocean surface layers is being released into the atmosphere. ${ }^{37,38,39}$ These DMS levels are in accordance with the concentrations of dimethylsulphoniopropionate and dimethylsulphide obtained from other studies carried out in the Eastern part of the Yellow Sea and China Sea. ${ }^{40}$

\section{CONCLUSION}

This study has shown that the concentrations in nanomolar (nM) of dimethylsulphide and dimethylsulphoniopropionate were successfully measured using the vapour generation chemiluminescence detection system. The two (2) sampling locations of Elegushi Beach and NIOMR, which are situated along the Gulf of Guinea, were used for this study. The average concentrations of DMSP and DMS in the surface seawater at the two locations ranged from $12.4 \pm 0.2$ to $26.5 \pm 0.5 \mathrm{nM}$, $2.1 \pm 0.0$ to $40.9 \pm 1.6 \mathrm{nM}$ and $9.7 \pm 0.4$ to $44.9 \pm 0.2 \mathrm{nM}, 0$ to $35.6 \pm 2.3 \mathrm{nM}$, respectively.

\section{ACKNOWLEDGMENT}

The funding and the publication of this research were supported by Covenant University. The first author thanks Dr. Ohira, Edwin Koveke, Daiki Okane and other students from the TODA-OHIRA laboratory, Kumamoto, Japan for their assistance during the construction of the VG-CL.

\section{REFERENCES}

1. M. Haworth, S. Catola, G. Marino, C. Brunetti, M. Michelozzi, E. Riggi and M. Centritto, Frontiers in Plant Science, 8, 1(2017), DOI:10.3389/fpls.2017.01016

2. M. L Otte, G. Wilson, J. T. Morris and B. M. Moran, Journal of Experimental Botany, 55(404), 1919(2004), DOI:10.1093/jxb/erh178

3. J. Yu, J. Y. Tian and G. P. Yang, Journal of Sea Research, 99, 17(2015), DOI:10.1016/j.seares.2015.01.004

4. H. Takahashi, S. Kopriva, M. Giordano, K. Saito and R. Hell, Annual Review of Plant Biology, 62, 157(2011), DOI:10.1146/annurev-arplant-042110-103921

5. E. Van Donk, A. Ianora, and M. Vos, Hydrobiologia, 668(1), 3(2010), DOI:10.1007/s10750-0100395-4

6. K. T. Park, K. Lee, K. Shin, E. J. Yang, B. Hyun, J. M. Kim and S. J. Choi, Environmental Science and Technology, 48(9), 4750(2014), DOI: 10.1021/es403351h

7. A. Trevena and G. Jones, Marine Chemistry, 134, 47(2012), DOI:10.1016/j.marchem.2012.03.001

8. M. Vancoppenolle, K. M. Meiners, C. Michel, L. Bopp, F. Brabant, G. Carnat and J. L. Tison, Quaternary Science Review, 79, 207(2013), DOI:10.1016/j.quascirev.2013.04.011

9. S. H. Zhang, J. Yu, Q.Y. Ding, G. P. Yang, K. S. Gao, H. H. Zhang and D. W. Pan, Biogeosciences, 15(21), 6649(2018), DOI:10.5194/bg-15-6649-2018

10. F. E. Hopkins, Doctoral dissertation, University of East Anglia, (2010),

11. N. Liu, S. Tong, X. Yi, Y. Li, Z. Li, H. Miao and Y. Wu, Marine Environmental Research, 129, 229(2017), DOI:10.1016/j.marenvres.2017.05.003

12. J. Harlay, A.V. Borges, C. Van Der Zee, B. Delille, R. H. M Godoi, L. S. Schiettecatte and S. Groom, Progress in Oceanography, 86(3-4), 317(2010), DOI:10.1016/j.pocean.2010.04.029

13. G. Speeckaert, A. V. Borges, W. Champenois, C. Royer and N. Gypens, Science of the Total Environmental, 622, 362(2018), DOI:10.1016/j.scitotenv.2017.11.359

14. J. Hill-Falkenthal, Doctoral dissertation, UC San Diego, (2014).

15. D. C. Yoch, Applied and Environmental Microbiology, 68(12), 5804(2002), DOI:10.1128/AEM.68.12.5804-5815.2002

16. C. R. Reisch, M. A. Moran and W. B. Whitman, Frontiers in Microbiology, 2(172), 1(2011), DOI: 10.3389/fmicb.2011.00172 


\section{RASĀYAN J. Chem.}

Vol. 13 | No. 1 |44 - 50| January - March | 2020

17. C. Y. Li, T. D. Wei, S. H. Zhang, X. L. Chen, X. Gao, P. Wang and J. Yu, Proceedings of the National Academy of Sciences, 111(3), 1026(2014), DOI: 10.1073/pnas.1312354111

18. J. B. Raina, E. A. Dinsdale, B. L. Willis and D. G. Bourne, Trends in Microbiology, 18(3), 101(2010), DOI: 10.1016/j.tim.2009.12.002

19. A. R. Curson, J. D Todd, M. J. Sullivan and A. W. Johnston, Nature Reviews Microbiology, 9(12), 849(2011), DOI: $10.1038 /$ nrmicro2653

20. M. Gali, C. Ruiz-Gonzalez, T. Lefort, J. M. Gasol, C. Cardelús, C. Romera-Castillo and R. Simó, Limnology and Oceanography, 58(2), 489(2013), DOI:10.4319/lo.2013.58.2.0489

21. A. Mellouki, T. J. Wallington and J. Chen, Chemical. Reviews, 115(10), 3984(2015), DOI: $10.1021 / \mathrm{cr} 500549$ n

22. M. Kulmala, A. Asmi, H. K. Lappalainen, U. Baltensperger, J. L. Brenguier, M. C. Facchini and A. Wiedensohler, Atmospheric Chemistry and Physics, 11(24), 13061(2011), DOI:10.5194/acp-1113061-2011

23. H. Korhonen, K. S. Carslaw, P. M. Forster, S. Mikkonen, N. D. Gordon and H. Kokkola, Geophysical Research Letters, 37(2) (2010), DOI:10.1029/2009GL041320

24. J. Schwinger, J. Tjiputra, N. Goris, K. D. Six, A. Kirkevåg, O .Seland and T. Ilyina, Biogeosciences, 14(15), 3633(2017), DOI:10.5194/bg-14-3633-2017

25. M. Lizotte, M. Levasseur, C. S. Law, C. F. Walker, K. A. Safi, A. Marriner and R. P. Kiene, Ocean Science, 13(6), 961(2017), DOI:10.5194/os-13-961-2017

26. X. Wu, T. Tan, C. Liu, T. Li, X. Liu and G. Yang, Journal of Ocean University of China. 17(2), 320(2018), DOI:10.1007/s11802-018-3541-7

27. F. S. Buckley and S. M. Mudge, Chemistry and Ecology, 20(2), 73(2004), DOI: $10.1080 / 02757540410001670209$

28. T. Tan, X. Wu, C. Liu and G. Yang, Continental Shelf Research, 146, 89(2017), DOI: $10.1016 /$ j.csr.2017.08.012

29. T. Nagahata, H. Kajiwara, S. I. Ohira and K. Toda, Analytical Chemistry, 85(9), 4461(2013), DOI: $10.1021 / \mathrm{ac} 303803 \mathrm{w}$

30. A. E. Adedapo, N. U. Benson, A. B. Williams, K. Toda. Journal of Physics, Conference Series, 1299, (1) (2019), DOI: $10.1088 / 1742-6596 / 1299 / 1 / 012132$

31. J. Stefels, G. Carnat, J. W. Dacey, T. Goossens, J. T. M. Elzenga and J. L. Tison, Marine Chemistry, 128, 34(2012), DOI:10.1016/j.marchem.2011.09.007

32. L. J Shiau, P. S Yu, K. Wei, M. Yamamoto, T. Q. Lee, E. F. Yu, T. Fang and M. T. Chen, Terrestrial Atmospheric Ocean Science, 19(4), 363(2008), DOI:10.3319/TAO.2008.19.4.363

33. O. Boucher, C. Moulin, S. Belviso, O. Aumont, L. Bopp, E. Cosme and J. Sciare, Atmospheric Chemistry and Physics, 3(1), 49(2003), DOI:10.5194/acp-3-49-2003

34. G. Kouvarakis and N. Mihalopoulos, Atmospheric Environment, 36, 929(2002), DOI:10.1016/S13522310(01)00511-8

35. S. D. Archer, G. C. Smith, P. D. Nightingale, C. E. Widdicombe, G. A. Tarran, A. P. Rees, Deep-Sea Research II, 49, 2979(2002), DOI:10.1016/S0967-0645(02)00067-X

36. R. P Kiene and T. S. Bates, Nature, 345, 702(1990), DOI:10.1038/345702a0

37. T. S. Bates, R. P. Kiene, G. V. Wolfe, P .A. Matrai, F .P. Chavez, K. R. Buck, B. W. Blomquist and R. L. Cuhel, Journal of Geophysics Research, 99, 7835(1994), DOI:10.1029/93JC02782

38. R. Simó and C Pedrós-Alió, Nature, 402, 396(1999), DOI: 10.1038/46516

39. G. Lee, J. Park, Y. Jang, M. Lee, K. R. Kim, J. R. Oh and T.Y Kim, Chemosphere, 78(8), 1063(2010), DOI:10.1016/j.chemosphere.2009.10.054

40. G. P. Yang, G. C. Zhuang, H. H. Zhang, Y. Dong, J. Yang, Marine Chemistry, 138, 21(2012), DOI:10.1016/j.marchem.2012.05.003

[RJC-5432/2019] 